\title{
Correlation of Breast Cancer with the Epstein Bar Virus and Human Cytomegalovirus Frequency and the Expression of Estrogen Receptor-Beta and IL-6 Receptor in Iraqi Women
}

\author{
Hayder Kadhim A. L. Shadood ${ }^{1,2}$, Saad Abdul-Aziz Atiya², Gholam Ali Kardar1,3* \\ ${ }^{1}$ Department of Medical Biotechnology, School of Advanced Technologies in Medicine, Tehran University of \\ Medical Sciences-International Campus, Tehran, Iran; ${ }^{2}$ Department of Microbiology, College of Medicine, \\ DHI-QAR University, DHI-QAR, Iraq; ${ }^{3}$ Immunology, Asthma \& Allergy Research Institute, Tehran University of \\ Medical Sciences, Tehran, Iran
}

Correspondence to: Gholam Ali Kardar, ${ }^{*}$ gakardar@tums.ac.ir

Keywords: Cytomegalovirus, Epstein-Barr Virus, Breast Cancer, Protein Expression

Received: September 27, $2017 \quad$ Accepted: May 18, $2018 \quad$ Published: May 21, 2018

Copyright $\odot 2018$ by authors and Scientific Research Publishing Inc.

This work is licensed under the Creative Commons Attribution International License (CC BY 4.0).

http://creativecommons.org/licenses/by/4.0/

\section{(c) (1) Open Access}

\section{ABSTRACT}

Background and Purpose: In Iraq, breast cancer is the common type of female malignancy. Increasing indication in the past 10 years proposes that Epstein-Barr virus (EBV) and cytomegalovirus (HCMV) are related with some human malignancies including breast cancer. The part of EBV and HCMV in breast cancer is still debatable. Unraveling this relationship is potentially essential for better understanding of breast cancer etiology, early recognition and possibly inhibition of breast cancer The purpose of the current study is to detect the correlation between EBV, HCMV and breast cancer in Iraqi women and expression of ERB and IL-6R in breast tissues. Patients and Methods: The study was done on paraffin-embedded tissues of eighty Iraqi patients with breast cancer in addition to twenty normal breast tissues as controls. Both controls and breast cancer mass are divided into two sections, one for DNA extraction and amplification by real time PCR for detect EBV and HCMV occurrence while the other section processed for protein expression (IL-6R, ERB) by immunohistochemistry technique (IHC). Results: The result showed that 18/80 (22.5\%) and 5/80 (6.25\%) sample from breast cancer were positive for EBV and HCMV respectively, with the $p$-value $=0.062$ and 0.597 and the results of IHC for IL-6R and ERB expression in patients with breast cancer were $37 / 80(46.25 \%)$ and $30 / 80(37.5 \%) p$-value $=(0.274$ and 0.381$)$ respectively. Conclusions: Our findings suggest that EBV might have a role in the pathogenesis of breast cancer and absence this role between HCMV with breast cancer. These findings were 


\section{based mainly on EBV, HCMV detection by PCR technique. So, the roles of these viruses in the development of breast cancer remain unclear.}

\section{INTRODUCTION}

Cancer progress is a difficult process containing the influence of many diverse reasons. The researchers identify numerous factors that subsidize in progresses of cancer action contain spontaneous, hereditary, microbes and contact of gene and environment. The head explanations about a likely infectious etiology of cancer ascended at the beginning of the previous century $[1,2]$. The infectious agents basis cancer by numerous mechanisms contain: (a) Introduction of chronic inflammation or prompt cell proliferation; (b) Direct carcinogenesis done DNA damage; (c) Destruction of immune responses against cancer.(d) Immune motivation of cancer growth factors [3-5].

Breast cancer is the most type of cancer in women worldwide [6]. Some human cancers can be produced by viruses e.g. mouse mammary tumor virus (MMTV) causes breast cancer in mice [7]. The scientists theorized that late contact (in adulthood rather than in childhood) to a common virus such as CMV or EBV can cause breast cancer $[8,9]$. HCMV had been revealed to be involved in several cancers comprising prostate, skin, colorectal and malignant glioma [10]. Increasing indication in the past 10 years proposes that HCMV is related with some human malignancies, and that HCMV gene yields can modify oncogenic properties of cells in vitro [11]. Since persistent of HCMV infection of breast epithelium may stimulate malignant transformation of infected breast epithelium, that wanted to define the HCMV gene products in usual and neoplastic breast [12]. There might be some mechanisms of how HCMV can reason breast cancer beginning and development. Firstly, it was revealed that HCMV gene yields disturb cell cycle regulation, prevent apoptosis, trigger angiogenesis and metastatic phenotype, and reason increased mutation rate, thus, overlapping with all recognized hallmarks of cancer cells [13]. Secondly, HCMV reveals immunosuppressive properties, leading to leakage of tumor cells from immune investigation mechanisms [14]. HCMV might have a part as an "oncomodulator" in altering the tumor microenvironment as well as in beginning and raise of tumor cells [15-18]. Recognition EBV in the neoplastic tissues of breast cancer samples has been recorded by several authors [19-24]. Most of the studies done to date to evaluate the link between EBV infection and breast carcinoma have been completed in Western countries; however, stable results have to be established from studies lead all over the world in order to found a causative association. So far, limited studies have been recorded from Asian countries [24-26] and from Egypt [27-29] the part of EBV in breast cancer is debatable [23, 25, 30-32] and a new study by QPCR proposed EBV might be an indicator of biological aggressiveness in breast cancer [33]. Three previous studies also proposed that breast cancer may be related with late infection and/or immune response to late infection [34-36]. There is sign for both EBV and HCMV as disruptors of telomere maintenance which may play a part in cancer progress $[37,38]$. However, two previous studies by QPCR for detection of EBV and breast cancer establish very little levels of EBV DNA in breast cancer tissue $[26,39]$ and a new study by immunohistochemistry (IHC) and in situ hybridization (ISH) establish EBV not in malignant cells but in infiltrating lymphocytes in breast cancer tissue [40].

\section{MATERIALS AND METHODS}

\section{Patients and tissue specimens}

This study was done on eighty samples Iraqi women patients with breast cancer which diagnosed by the histopathology department, in addition to twenty normal breast tissue samples as a control group. All patients were newly diagnosed and just three of them had a previous history of breast carcinoma. Paraffin blocks of breast tissues were obtained from the Pathology Departments of Imam Hussein Teaching Hospital in Nasiriya province in Iraq, from august 2015 to march 2017. For each tumor block, divided into two sections the first cut onto positive charged slides for immunohistochemistry (IHC). Another section was cut into a sterile Eppendorf tube for DNA extraction and real time PCR. A consent form was obtained 
from all patients prior to enrollment in the study.

\section{DNA extraction}

DNA was extracted from FFPE tissue sections by using (DNA Extraction Kit Geneaid. USA) and done according to company instruction, the extracted DNA was checked by using Nano drop spectrophotometer (THERMO. USA), that check and measurement the purity of DNA through reading the absorbance in at $(260 / 280 \mathrm{~nm})$ and storage at $-20^{\circ} \mathrm{C}$ freezer.

Primers and probes: as we mentioned in Table 1.

\section{Real-Time Polymerase chain reaction}

Real-Time PCR technique was performed for detection of Human cytomegalovirus and Epstein-Barr virus. This technique was carried out according to method described by (Richardson et al., 2015) as following steps: Real-Time PCR master mix preparation: qPCR master mix was prepared by using (GoTaq ${ }^{\circledR}$ Probe qPCR Master Mix) and this master mix done according to company instructions) DNA template 5 $\mu \mathrm{L}$, Forward \& Reverse primer $1 \mu \mathrm{L}(10 \mathrm{pmol})$, probe $1 \mu \mathrm{L}(20 \mathrm{pmol}), 10 \mu \mathrm{L}$ qPCR master mix, and $2 \mu \mathrm{L}$ water. After that, these PCR master mix component that mentioned in above transferred into Exispin vortex centrifuge at $3000 \mathrm{rpm}$ for 3 minutes, then placed in Real-time PCR Thermocycler (BioRad, USA). Real-Time PCR thermocycler conditions was set according to primer annealing temperature and qPCR TaqMan kit instructions by Biorad Real-Time PCR thermocycler system as in the following Pre-Denaturation $95^{\circ} \mathrm{C}, 5 \mathrm{~min}$ for 1 cycle, Denaturation $95^{\circ} \mathrm{C}, 20 \mathrm{sec}$, Annealing/Extension Detection (Scan) $60^{\circ} \mathrm{C} 30 \mathrm{sec}$ for $45 \mathrm{cycles}$. qPCR data analysis was performed by calculation the threshold cycle number (CT value) that presented the positive amplification in Real-Time PCR cycle number.

\section{Immunohistochemistry}

The standard Streptavidin-biotin-peroxidase detection technique was performed according manufacture instruction for detect estrogen receptor beta antibody: $\operatorname{ERB}(\mathrm{B}-3)$ : $\operatorname{ERB}(\mathrm{B}-3)$ is a mouse monoclonal antibody (santacruz biotechnology USA) and IL-6 receptors antibody (santacruz biotechnology USA). The antigen retrieval method was performed by microwave pretreatment in $0.01 \mathrm{M}$ citrate buffer ( $\mathrm{pH}$ 6.0). Manufacturer's protocols were followed for all procedures. The primary antibody was applied and incubated overnight at $4^{\circ} \mathrm{C}$ in a humidified chamber and after 3 washes in PBS, the secondary antibody and the avidin-biotin complex $(\mathrm{ABC})$ were applied to slides. Diaminobenzidine (DAB) was used as a chromogen and sections were counterstained using Mayer's hematoxylin. To evaluate the specificity of the antibodies, known positive and negative tissues were used as controls. Cases were considered positive with $>10 \%$ stained cells.

\section{Statistical analysis:}

Statistical analysis of all obtained data, are reported as mean \pm SD. Significant differences between the data were assessed by Student's t-test. The values of $p<0.05$ were considered significant. The Pearson correlation test was used for correlation analysis. All statistical analysis and correlation graphs were performed using SPSS 18 software. All experiments were replicated twice with triplicate repeated measures.

Table 1. The primers and probes used for detection of HCMV and EBV.

\begin{tabular}{ccccc}
\hline Primer & & Sequence & Amplicon & Gen Bank \\
\hline HCMV primers & $\mathrm{F}$ & ACGCGTAGAAGCAAGAGAAG & $119 \mathrm{bp}$ & \\
& $\mathrm{R}$ & ATGTAGTTGCGCAACGTGTC & & AF043720.1 \\
HCMV probe & & FAM-TGTGCTTTACGCCCAGCTGCA-BHQ1 & \\
& $\mathrm{F}$ & TCATGAACGTGCCTTTGGTG & $78 \mathrm{bp}$ & FJ594486.1 \\
EBV primers & $\mathrm{R}$ & AGCTGTTCACAAAGGCAAGC & & \\
EBV probe & & FAM-ACCTACTGGGAACGGGCAGGG-BHQ1 & \\
\hline
\end{tabular}




\section{RESULTS}

The present study shows that 18 of 80 (22.5\%) patient with breast cancer was positive for EBV, while the EBV was positive for just 2 of 20 of control (Table 2). But, the CMV was positive in 5 of 80 (6.25\%) for breast cancer patients and 1 of 20 (5\%) for control by QPCR method with p-value $(0.062$ and 0.597 respectively) (Table 3). the detection of receptors expression was shown in Table 4 \& Table 5 for ERB and IL-6R, respectively. The ERB was positive (Figure 1) for 37 of $80(46.25 \%)$ women with breast cancer, nevertheless 9 of 20 (45\%) of control group their ERB was positive. IL-6R was positive in 30 of 80 (37.5\%) of patients having breast cancer, and 9 of 20 (45\%) in control.

\section{DISCUSSION}

EBV was categorized as a group-1 carcinogen via IARC Working Group [41]. However, the related

Table 2. The frequency of EBV in breast cancer and normal breast tissues.

\begin{tabular}{lrccc}
\hline Virus & Group & Breast cancer & Normal tissue & Association \\
\hline \multirow{2}{*}{ EBV } & Positive & 18 & 2 & $P$-value 0.062 no significant No relation \\
& Negative & 62 & 18 & between EBV and breast cancer \\
\multicolumn{2}{l}{ Total positive (\%) } & $18 / 80(22.5 \%)$ & $2 / 20(10 \%)$ & \\
\hline
\end{tabular}

Table 3. HCMV frequency in the breast tissues from healthy and breast cancer women.

\begin{tabular}{ccccc}
\hline Virus & Group & Breast cancer & Normal tissue & Association \\
\hline \multirow{2}{*}{ HCMV } & Positive & 5 & 1 & $P$-value 0.597 no significant No relation \\
& $\begin{array}{c}\text { Negative } \\
\text { Total positive (\%) }\end{array}$ & 75 & 19 & between HCMV and breast cancer \\
\hline
\end{tabular}

Table 4. ERB expression in breast tissues of breast cancer and healthy women.

\begin{tabular}{lcccc}
\hline & Group & Breast cancer & Normal tissue & Association \\
\hline \multirow{2}{*}{ ERB } & Positive & 37 & 9 & $P$-value 0.274 no significant No relation \\
& Negative & 43 & 11 & between ERB and breast cancer \\
\multicolumn{2}{l}{ Total positive (\%) } & $37 / 80(46.25 \%)$ & $9 / 20(45 \%)$ & \\
\hline
\end{tabular}

Table 5. IL-6 receptors expression in breast tissues of breast cancer and healthy women.

\begin{tabular}{lcccc}
\hline & Group & Breast cancer & Normal tissue & Association \\
\hline IL-6 R & Positive & 30 & 9 & $P$-value 0.381 no significant No relation \\
& Negative & 50 & 11 & between IL-6R and breast cancer \\
\multicolumn{2}{c}{ Total positive (\%) } & $30 / 80(37.5 \%)$ & $9 / 20(45 \%)$ & \\
\hline
\end{tabular}



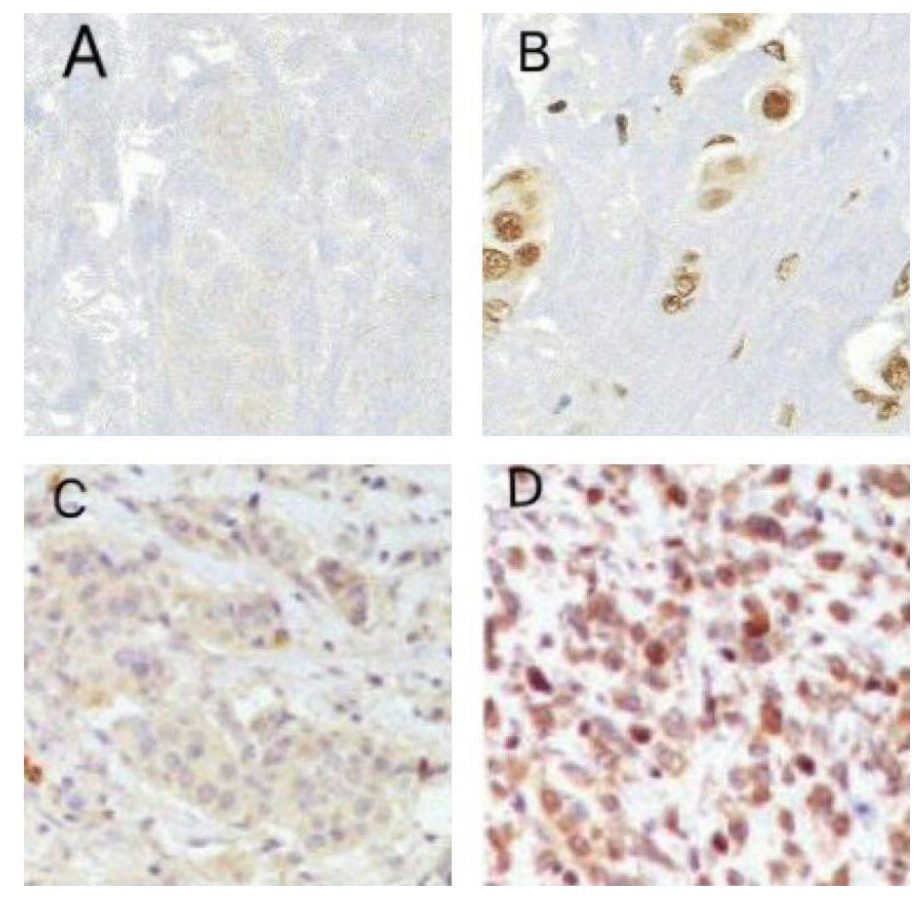

Figure 1. ERB and IL-6R expression by immune-histochemistry staining. (A) ERB negative; (B) ERB positive; (C) IL-6R negative; (D) IL-6R positive.

cancers differ markedly in viral incidence, from approximately $100 \%$ of (NPCs) to around $10 \%$ of gastric carcinomas [42-44], and likewise vary in the designs of viral genes expressed, proposing that EBV may disturb cell progress in more than one mode [44]. Thus, EBV infection signifies an essential but not an adequate step in carcinogenesis and epidemiological risk factors have been revealed to play an extra dire part in this manner. Indirect support for a link of EBV with breast cancer derives from opinions that: a) EBV is existing in breast tissue, where it is identified in breast milk in a number of women [45]; b) transfection of EBV DNA motivates progress of human breast milk cells [46]; c) certain EBV-associated lymphomas happen in the breast $[47,48]$; d) breast cancer has epidemiological likenesses to young-adult (Hodgkin's lymphoma), though indication for breast cancer accuses timing of primary EBV infection rather than viral oncogenesis [9]; e) EBV has been recognized in normal breast tumors in immunosuppressed women [49]; f) in vitro: breast epithelial cells can be diseased by direct connection with EBV-bearing lymphoblastoid cell lines [50]; and g) Concerning serological indication, quantity levels of anti-EBNA-1 (IgG) antibodies in kept sera of breast cancer Indian women was before prepared by Joshi $e t$ al. using commercial (ELISA) kit, in which patients with normal breast diseases were used as a contrast group for both IHC and serological examination.

Our results have shown that EBV positivity in breast cancer samples in $18 / 80$ was (22.5\%), the EBV have not verified in association with case samples and the presence of EBV was not significant besides breast cancer ( $p$-value $=0.062, \mathrm{df}=1$ ). The result was near to the previous study prepared by Joshi et al., [24]. Where they establish that around (55\%) of breast cancer Indian women cases showed (EBNA-1) expression in tumor cells by (IHC) but wholly the controls with normal breast tumor were negative. Also, two Egyptian authors Mohamed et al. 1994 and Fawzy et al. 2008 [29, 51] have testified EBV infection in $(35.3 \%)$ and $(25 \%)$ of invasive breast carcinoma respectively. nevertheless, those three studies had some limits, where they observed for expression of only one viral protein. They should have studied several EBV proteins existing in diverse stages of viral dormancy seen in other EBV linked tumors. Moreover, our results are near to several studies [19, 20,23,51-55], where EBV infection has been found most steadily and in a incidence of roughly $(10 \%-50 \%)$ by use PCR method, and (IHC) methods have produced indication of viral DNA or proteins inside the breast cancer cells that proposes a pathogenic role of (EBV). Though 
EBV infection has been created by some authors, it has been completely hidden by others [56-59]. The conflict and obvious inconsistency of these results should not itself ignore a role of EBV in breast carcinogenesis because it is influenced to certain range by three matters: First, the marked difference in EBV incidence even among studies by the similar methods $[23,52,60]$. Second, the likelihood of false-positive or -negative investigative test results due to lymphocyte-derived EBV, cross-reactivity immunostains, amplicon impurity, or unsuitable method sensitivity. And the latter matter is the lack of EBV-cancer link hallmarks containing (EBERs) expression in all cells of virus related tumors. Breast cancer can express (EBERs) less copiously than other malignancies [20-23]. Nevertheless, (EBERs) are not established in all (NPCs) or in certain Burkitt and Hodgkin lymphomas that are (LMP-1) positive by PCR [25, 26, 61]. Luqmani and Shousha (1995) [19] From England obtained 28 Invasive and carcinoma (Nested PCR for BamH1W was 54\%, ISH for EBER was 0\% And IHC for LMP1 Focal positive) Brink et al. (2000) [52] From Holland obtained 24 Carcinoma and the results were (PCR for BamH1W 21\%, PCR for LMP1 $2 / 5$ (40\%) PCR+, rtPCR for BamH1A RNA 0/5 PCR+, rtPCR for EBNA1 RNA 0/5 PCR+, IHC for EBNA1 1/5 (20\%) PCR+ and ISH for EBER1/2 0/5 PCR+) Kijima et al. (2001) [59] From Japan obtained 61 Carcinoma (ISH for EBER1 0\%) Chu et al. (2001) [62] From US obtained 48 Invasive and carcinoma (IHC for EBNA1 25\%, IHC for LMP1 0\%, IHC for BZLF1 0\%, ISH for EBER1 10\%, PCR for EBNA-4 (EBNA-3b) 10\%, PCR for LMP1 10\% and Southern blot for EBV clonality 0/6 PCR+).

Quantitative real time PCR done to qualitative finding of cytomegalovirus DNA in DNA samples that extracted from tissue sample of breast cancer. The result revealed just five from 80 (6.25\%) sample was positive not show the significant levels of HCMV. Therefore, the correlation is not established between HCMV and breast cancer ( $p$-value $=0.597, \mathrm{df}=1$ ). These results differ with several studies indicated to the link of HCMV with breast cancer, but different results had been presented. This result complete by Harkins LE. et al., 2010 [11] when used (PCR) and (ISH) to identify HCMV DNA in the breast ductal carcinoma in situ (DCIC) and invasive ductal carcinoma (IDC). In addition to that, Al-Alwany and Ali, 2013 [63] CMV was demonstrated by ISH in (34.3\%) breast cancer tissues 24 out of 70 which statistically show highly significant difference $(p<0.001)$ when compared to the control breast tissues group (all were negative by ISH for CMV-DNA).In contrast, Utera-Barillas et al., 2013 [64] study indication no link between HCMV infection and breast cancer development when used real time PCR to identify HCMV DNA in the samples of breast cancer tissue Two carcinomas were positive for HCMV, one was positive for two TaqMan viral detection probes, and one was positive for a sole TaqMan viral detection probe (UL83), whereas the remainder of the samples was negative. Additional studies also used normal breast tissue as control and the results were similar, certain studies displayed lack of the HCMV DNA in the normal breast tissue while others presented (63\%) of HCMV DNA existing in normal epithelial breast tissue Harkins et al., 2010) [11]. Recent examinations have related viral infections such as (EBV, MMTV, HPV and HCMV) to breast cancer (Lee and Schmitt, 2003) [65]. Human cytomegalovirus had be revealed to be implicated in many cancers such a malignant glioma, and prostate, skin, and colorectal cancers. As revealed above, HCMV had several mechanisms implicated in the progression of the cancer. First indication indicated to the relationship between HCMV and breast cancer was the shedding of the virus with breast milk and existence of the epithelial cells in breast tissue, which consider the leading tropism cell for HCMV. HCMV prompts inflammation and at the same time exploits sophisticated ways to escape immune recognition $[66,67]$.

The results of our study support an unlikely relationship between EBV and breast cancer but not CMV and breast cancer while some earlier studies of CMV and EBV IgG levels found an association between high IgG levels and breast cancer for CMV but not EBV. These results, together with the results of other studies of EBV and CMV and breast cancer, propose several possibilities including differences in the techniques that used for detection of viruses in addition to the limitations of molecular analyses mean that these analyses may not be confirm whether, one, both, or neither virus is associated with breast cancer; however, sensitivity may be increased by using ISH in addition to PCR for precise diagnosis.

Our results showed (46.25\%) and (45\%) of patients and control were express ERB respectively. While, IL-6R expression was seen in (37.5\%), (45\%) of cancer and normal tissue samples respectively. Interleu- 
kin-6 (IL-6) is a pleiotropic cytokine that interacts with its specific receptor in different cells involving malignant ones, thus regulating proliferative response and differentiation. Chronic inflammation is associated with a number of tumors through a number of inflammatory mediators such as cytokines. proinflammatory cytokines play critical roles in the pathogenesis of cancer involving IL-6, IL-8 and TNF- $\alpha$ that lead to tumor endorsement, invasion, and angiogenesis. IL-6 signaling has been implicated in directive of tumor growth and metastatic spread, and its level could be linked with poor prognosis in different cancers. In addition, high IL-6 serum levels were reported to be associated with metastasis and poor prognosis of prostate, ovarian, and bladder cancers [68]. Estrogen receptor $\beta$, there are two different estrogen receptors in man, estrogen receptor $\alpha$ and estrogen receptor $\beta$, which are encoded by two distinct genes, ESR 1 and ESR2. ER $\alpha$ mediates most of the proliferative effects in female reproductive tissues. In contrast, ER $\beta$ appears to act mostly as an inhibitor of ER $\alpha$ action, and perhaps even of the androgen receptor in males. The two estrogen receptors are expressed in different patterns throughout the human body [69].

\section{CONCLUSION}

Our findings suggest that EBV might have a role in the pathogenesis of breast cancer and absence this role between HCMV with breast cancer. These findings were based mainly on EBV, HCMV detection by PCR technique. So, EBV may contribute to increased tumor aggression. Neither virus has a role in breast cancer development. Future studies should focus on ways to investigate these possibilities and should include more samples and should focus on several viruses' proteins and use development techniques.

\section{DECLARATIONS}

\section{ACKNOWLEDGEMENTS}

This study was financially supported by the international campus of Tehran University of Medical Sciences (Grant \#35346).

\section{AUTHORS' CONTRIBUTIONS}

Hayder designed the study, edited the final version of the manuscript, conducted the sample analysis provided the clinical samples and drafted the paper; Saad contributed to the statistical analyses; Gholam Ali Kardar supervised the whole project. All authors read and approved the final manuscript.

\section{ETHICS APPROVAL AND CONSENT TO PARTICIPATE}

The study was reviewed and approved by the Medical Ethics Committee of Tehran University of Medical Sciences and Imam Hussein Teaching Hospital. All study participants, or their legal suppose, provided informed written consent prior to study enrollment.

\section{COMPETING INTERESTS}

The authors declare that they have no competing interests.

\section{REFERENCES}

1. Parkin, D.M. (2006) The Global Health Burden of Infection-Associated Cancers in the Year 2002. International Journal of Cancer, 118, 3030-3044. https://doi.org/10.1002/ijc.21731

2. Blaser, M.J. (2008) Understanding Microbe-Induced Cancers. Cancer Prevention Research, 1, 15-20. https://doi.org/10.1158/1940-6207.CAPR-08-0024

3. Lax, A.J. (2005) Bacterial Toxins and Cancer-A Case to Answer? Nature Reviews Microbiology, 3, 343-349. https://doi.org/10.1038/nrmicro1130 
4. Tamburini, J., Grimaldi, D., Chiche, J.-D., Bricaire, F. and Bossi, P. (2007) Cytokine Pattern in Kaposi’s Sarcoma Associated with Immune Restoration Disease in HIV and Tuberculosis Co-Infected Patients. AIDS, 21, 1980-1983. https://doi.org/10.1097/QAD.0b013e3282efa62c

5. Ohshima, H. and Bartsch, H. (1994) Chronic Infections and Inflammatory Processes as Cancer Risk Factors: Possible Role of Nitric Oxide in Carcinogenesis. Mutation Research/Fundamental and Molecular Mechanisms of Mutagenesis, 305, 253-264. https://doi.org/10.1016/0027-5107(94)90245-3

6. Jemal, A., Bray, F., Center, M.M., Ferlay, J., Ward, E. and Forman, D. (2011) Global Cancer Statistics. CA: $A$ Cancer Journal for Clinicians, 61, 69-90. https://doi.org/10.3322/caac.20107

7. Hennighausen, L. (2000) Mouse Models for Breast Cancer. Breast Cancer Research, 2, 2. https://doi.org/10.1186/bcr20

8. Richardson, A. (1997) Is Breast Cancer Caused by Late Exposure to a Common Virus? Medical Hypotheses, 48, 491-497. https://doi.org/10.1016/S0306-9877(97)90118-3

9. Yasui, Y., Potter, J.D., Stanford, J.L., Rossing, M.A., Winget, M.D., Bronner, M., et al. (2001) Breast Cancer Risk and "Delayed" Primary Epstein-Barr Virus Infection. Cancer Epidemiology and Prevention Biomarkers, 10, 9-16.

10. Alibek, K., Kakpenova, A., Mussabekova, A., Sypabekova, M. and Karatayeva, N. (2013) Role of Viruses in the Development of Breast Cancer. Infectious Agents and Cancer, 8, 32. https://doi.org/10.1186/1750-9378-8-32

11. Harkins, L.E., Matlaf, L.A., Soroceanu, L., Klemm, K., Britt, W.J., Wang, W., et al. (2010) Detection of Human Cytomegalovirus in Normal and Neoplastic Breast Epithelium. Herpesviridae, 1, 8. https://doi.org/10.1186/2042-4280-1-8

12. Cox, B., Richardson, A., Graham, P., Gislefoss, R., Jellum, E. and Rollag, H. (2010) Breast Cancer, Cytomegalovirus and Epstein-Barr Virus: A Nested Case-Control Study. British Journal of Cancer, 102, 1665-1669. https://doi.org/10.1038/sj.bjc.6605675

13. Dziurzynski, K., Chang, S.M., Heimberger, A.B., Kalejta, R.F., McGregor Dallas, S.R., Smit, M., et al. (2012) Consensus on the Role of Human Cytomegalovirus in Glioblastoma. Neuro-Oncology, 14, 246-255. https://doi.org/10.1093/neuonc/nor227

14. Zhu, H., Shen, Y. and Shenk, T. (1995) Human Cytomegalovirus IE1 and IE2 Proteins Block Apoptosis. Journal of Virology, 69, 7960-7970.

15. Söderberg-Nauclér, C. (2008) HCMV Microinfections in Inflammatory Diseases and Cancer. Journal of Clinical Virology, 41, 218-223. https://doi.org/10.1016/j.jcv.2007.11.009

16. Michaelis, M., Doerr, H.W. and Cinatl, J. (2009) The Story of Human Cytomegalovirus and Cancer: Increasing Evidence and Open Questions. Neoplasia, 11, 1-19. https://doi.org/10.1593/neo.81178

17. Soroceanu, L. and Cobbs, C.S. (2011) Is HCMV a Tumor Promoter? Virus Research, 157, 193-203. https://doi.org/10.1016/j.virusres.2010.10.026

18. Baryawno, N., Rahbar, A., Wolmer-Solberg, N., Taher, C., Odeberg, J., Darabi, A., et al. (2011) Detection of Human Cytomegalovirus in Medulloblastomas Reveals a Potential Therapeutic Target. The Journal of Clinical Investigation, 121, 4043-4055. https://doi.org/10.1172/JCI57147

19. Luqmani, Ya. and Shousha, S. (1995) Presence of Epstein-Barr-Virus in Breast-Carcinoma. International Journal of Oncology, 6, 899-903. https://doi.org/10.3892/ijo.6.4.899

20. Labrecque, L.G., Barnes, D.M., Fentiman, I.S. and Griffin, B.E. (1995) Epstein-Barr Virus in Epithelial Cell Tumors: A Breast Cancer Study. Cancer Research, 55, 39-45.

21. Chu, J.-S., Chen, C.-C. and Chang, K.-J. (1998) In Situ Detection of Epstein-Barr Virus in Breast Cancer. Cancer Letters, 124, 53-57. https://doi.org/10.1016/S0304-3835(97)00449-7 
22. Glaser, S.L., Ambinder, R.F., DiGiuseppe, J.A., Horn-Ross, P.L. and Hsu, J.L. (1998) Absence of Epstein-Barr Virus EBER-1 Transcripts in an Epidemiologically Diverse Group of Breast Cancers. International Journal of Cancer, 75, 555-558. https://doi.org/10.1002/(SICI)1097-0215(19980209)75:4<555::AID-IJC10>3.0.CO;2-8

23. Bonnet, M., Guinebretiere, J.-M., Kremmer, E., Grunewald, V., Benhamou, E., Contesso, G., et al. (1999) Detection of Epstein-Barr Virus in Invasive Breast Cancers. Journal of the National Cancer Institute, 91, 1376-1381. https://doi.org/10.1093/jnci/91.16.1376

24. Joshi, D., Quadri, M., Gangane, N., Joshi, R. and Gangane, N. (2009) Association of Epstein Barr Virus Infection (EBV) with Breast Cancer in Rural Indian Women. PLoS One, 4, e8180.

https://doi.org/10.1371/journal.pone.0008180

25. He, J.-R., Tang, L.-Y., Yu, D.-D., Su, F.-X., Song, E.-W., Lin, Y., et al. (2011) Epstein-Barr Virus and Breast Cancer: Serological Study in a High-Incidence Area of Nasopharyngeal Carcinoma. Cancer Letters, 309, 128-136. https://doi.org/10.1016/j.canlet.2011.05.012

26. Perrigoue, J.G., Den Boon, J.A., Friedl, A., Newton, M.A., Ahlquist, P. and Sugden, B. (2005) Lack of Association between EBV and Breast Carcinoma. Cancer Epidemiology and Prevention Biomarkers, 14, 809-814. https://doi.org/10.1158/1055-9965.EPI-04-0763

27. Bahnassy, A., Zekri, A., Asaad, N., El-Houssini, S., Khalid, H., Sedky, L., et al. (2006) Epstein-Barr Viral Infection in Extranodal Lymphoma of the Head and Neck: Correlation with Prognosis and Response to Treatment. Histopathology, 48, 516-528. https://doi.org/10.1111/j.1365-2559.2006.02377.x

28. Mohamed, W.S., Mohamed, M.A. and Omar, M.M. (2007) Possible Involvement of Epstein-Barr Virus (EBV) in Pathogenesis and Prognosis of Female Breast Infiltrating Duct Carcinoma: Clinicopathological, Immunohistochemical and Molecular Study. The Egyptian Society of Medical Microbiology, 16, 403-414.

29. Fawzy, S., Sallam, M. and Awad, N.M. (2008) Detection of Epstein-Barr Virus in Breast Carcinoma in Egyptian Women. Clinical Biochemistry, 41, 486-492. https://doi.org/10.1016/j.clinbiochem.2007.12.017

30. Magrath, I. and Bhatia, K. (1999) Breast Cancer: A New Epstein-Barr Virus-Associated Disease? Journal of the National Cancer Institute, 91, 1349-1350. https://doi.org/10.1093/jnci/91.16.1349

31. Fina, F., Romain, S., Ouafik, L.H., Palmari, J., Ayed, F.B., Benharkat, S., et al. (2001) Frequency and Genome Load of Epstein-Barr Virus in 509 Breast Cancers from Different Geographical Areas. British Journal of Cancer, 84, 783-790. https://doi.org/10.1054/bjoc.2000.1672

32. Xue, S., Lampert, I., Haldane, J., Bridger, J. and Griffin, B. (2003) Epstein-Barr Virus Gene Expression in Human Breast Cancer: Protagonist or Passenger? British Journal of Cancer, 89, 113. https://doi.org/10.1038/sj.bjc.6601027

33. Mazouni, C., Fina, F., Romain, S., Ouafik, L., Bonnier, P., Brandone, J., et al. (2011) Epstein-Barr Virus as a Marker of Biological Aggressiveness in Breast Cancer. British Journal of Cancer, 104, 332-337. https://doi.org/10.1038/sj.bjc.6606048

34. Stewart, T., Tsai, S.-C., Grayson, H., Henderson, R. and Opelz, G. (1995) Incidence of De-Novo Breast Cancer in Women Chronically Immunosuppressed after Organ Transplantation. The Lancet, 346, 796-798. https://doi.org/10.1016/S0140-6736(95)91618-0

35. Savu, A., Potter, J., Li, S. and Yasui, Y. (2008) Breast Cancer and Microbial Cancer Incidence in Female Populations around the World: A Surprising Hyperbolic Association. International Journal of Cancer, 123, 1094-1099.

36. Hjalgrim, H., Askling, J., Sørensen, P., Madsen, M., Rosdahl, N., Storm, H.H., et al. (2000) Risk of Hodgkin's Disease and Other Cancers after Infectious Mononucleosis. Journal of the National Cancer Institute, 92, 1522-1528. https://doi.org/10.1093/jnci/92.18.1522

37. Kamranvar, S. and Masucci, M. (2011) The Epstein-Barr Virus Nuclear Antigen-1 Promotes Telomere Dysfunc- 
tion via Induction of Oxidative Stress. Leukemia, 25, 1017-1025. https://doi.org/10.1038/leu.2011.35

38. Strååt, K., Liu, C., Rahbar, A., Zhu, Q., Liu, L., Wolmer-Solberg, N., et al. (2009) Activation of Telomerase by Human Cytomegalovirus. Journal of the National Cancer Institute, 101, 488-497. https://doi.org/10.1093/jnci/djp031

39. Perkins, R.S., Sahm, K., Marando, C., Dickson-Witmer, D., Pahnke, G.R., Mitchell, M., et al. (2006) Analysis of Epstein-Barr Virus Reservoirs in Paired Blood and Breast Cancer Primary Biopsy Specimens by Real Time PCR. Breast Cancer Research, 8, R70. https://doi.org/10.1186/bcr1627

40. Khan, G., Philip, P.S., Al Ashari, M., Houcinat, Y. and Daoud, S. (2011) Localization of Epstein-Barr Virus to Infiltrating Lymphocytes in Breast Carcinomas and Not Malignant Cells. Experimental and Molecular Pathology, 91, 466-470. https://doi.org/10.1016/j.yexmp.2011.04.018

41. Virus, E.-B. and Humans, I.W. (1997) GotEoCRt, Cancer IAfRo. Epstein-Barr Virus and Kaposi's Sarcoma, Herpesvirus/Human Herpesvirus. IARC Monographs on the Evaluation of Carcinogenic Risks to Humans, 70.

42. Hsu, J.L. and Glaser, S.L. (2000) Epstein-Barr Virus-Associated Malignancies: Epidemiologic Patterns and Etiologic Implications. Critical Reviews in Oncology/Hematology, 34, 27-53. https://doi.org/10.1016/S1040-8428(00)00046-9

43. Gulley, M.L. (2001) Molecular Diagnosis of Epstein-Barr Virus-Related Diseases. The Journal of Molecular Diagnostics, 3, 1-10. https://doi.org/10.1016/S1525-1578(10)60642-3

44. Niedobitek, G., Meru, N. and Delecluse, H.J. (2001) Epstein-Barr Virus Infection and Human Malignancies. International Journal of Experimental Pathology, 82, 149-170. https://doi.org/10.1111/j.1365-2613.2001.iep190.x

45. Junker, A.K., Thomas, E.E., Radcliffe, A., Forsyth, R.B., Davidson, A.G.F. and Rymo, L. (1991) Epstein-Barr Virus Shedding in Breast Milk. The American Journal of the Medical Sciences, 302, 220-223. https://doi.org/10.1097/00000441-199110000-00005

46. Glenn, W., Heng, B., Delprado, W., Iacopetta, B. and Whitaker, N. (2012) Epstein-Barr Virus, Human Papillomavirus and Mouse Mammary Tumour Virus as Multiple Viruses in Breast Cancer. PLoS One, 7, e48788. https://doi.org/10.1371/journal.pone.0048788

47. Giardini, R., Piccolo, C. and Rilke, F. (1992) Primary Non-Hodgkin's Lymphomas of the Female Breast. Cancer, 69, 725-735. https://doi.org/10.1002/1097-0142(19920201)69:3<725::AID-CNCR2820690320>3.0.CO;2-C

48. Abhyankar, S., Chiang, K., McGuirk, J., Pati, A., Godder, K., Welsh, J., et al. (1998) Late Onset Epstein-Barr Virus-Associated Lymphoproliferative Disease after Allogeneic Bone Marrow Transplant Presenting as Breast Masses. Bone Marrow Transplantation, 21, 295-297. https://doi.org/10.1038/sj.bmt.1701070

49. Kleer, C.G., Tseng, M.D., Gutsch, D.E., Rochford, R.A., Wu, Z., Joynt, L.K., et al. (2002) Detection of Epstein-Barr Virus in Rapidly Growing Fibroadenomas of the Breast in Immunosuppressed Hosts. Modern Pathology, 15, 759-764. https://doi.org/10.1038/modpathol.3880602

50. Speck, P. and Longnecker, R. (2000) Infection of Breast Epithelial Cells with Epstein-Barr Virus via Cell-to-Cell Contact. Journal of the National Cancer Institute, 92, 1849-1851. https://doi.org/10.1093/inci/92.22.1849

51. Horiuchi, K., Mishima, K., Ohsawa, M. and Aozasa, K. (1994) Carcinoma of Stomach and Breast with Lymphoid Stroma: Localisation of Epstein-Barr Virus. Journal of Clinical Pathology, 47, 538-540. https://doi.org/10.1136/jcp.47.6.538

52. Brink, A.A., van den Brule, A.J., van Diest, P. and Meijer, C.J. (2000) Re: Detection of Epstein-Barr Virus in Invasive Breast Cancers. Journal of the National Cancer Institute, 92, 655-656.

https://doi.org/10.1093/jnci/92.8.655

53. Grinstein, S., Preciado, M.V., Gattuso, P., Chabay, P.A., Warren, W.H., De Matteo, E., et al. (2002) Demonstration of Epstein-Barr Virus in Carcinomas of Various Sites. Cancer Research, 62, 4876-4878. 
54. Preciado, M.V. (2003) Lack of Evidence for an Association of Epstein-Barr Virus Infection with Breast Carcinoma-Another Point of View. Breast Cancer Research, 5, E6. https://doi.org/10.1186/bcr599

55. Lorenzetti, M.A., De Matteo, E., Gass, H., Vazquez, P.M., Lara, J., Gonzalez, P., et al. (2010) Characterization of Epstein Barr virus Latency Pattern in Argentine Breast Carcinoma. PLoS One, 5, e13603. https://doi.org/10.1371/journal.pone.0013603

56. Gaffey, M., Frierson Jr., H., Mills, S., Boyd, J., Zarbo, R., Simpson, J., et al. (1993) Medullary Carcinoma of the Breast. Identification of Lymphocyte Subpopulations and Their Significance. Modern Pathology: An Official Journal of the United States and Canadian Academy of Pathology, 6, 721-728.

57. Lespagnard, L., Cochaux, P., Larsimont, D., Degeyter, M., Velu, T. and Heimann, R. (1995) Absence of Epstein-Barr Virus in Medullary Carcinoma of the Breast as Demonstrated by Immunophenotyping, In Situ Hybridization and Polymerase Chain Reaction. American Journal of Clinical Pathology, 103, 449-452.

https://doi.org/10.1093/ajcp/103.4.449

58. Dadmanesh, F., Peterse, J., Sapino, A., Fonelli, A. and Eusebi, V. (2001) Lymphoepithelioma-Like Carcinoma of the Breast: Lack of Evidence of Epstein-Barr Virus Infection. Histopathology, 38, 54-61. https://doi.org/10.1046/j.1365-2559.2001.01055.x

59. Kijima, Y., Hokita, S., Takao, S., Baba, M., Natsugoe, S., Yoshinaka, H., et al. (2001) Epstein-Barr Virus Involvement Is Mainly Restricted to Lymphoepithelial Type of Gastric Carcinoma among Various Epithelial Neoplasms. Journal of Medical Virology, 64, 513-518. https://doi.org/10.1002/jmv.1079

60. Glaser, S.L., Hsu, J.L. and Gulley, M.L. (2004) Epstein-Barr Virus and Breast Cancer: State of the Evidence for Viral Carcinogenesis. Cancer Epidemiology and Prevention Biomarkers, 13, 688-697.

61. Mant, C., Hodgson, S., Hobday, R., D’Arrigo, C. and Cason, J. (2004) A Viral Aetiology for Breast Cancer: Time to Re-Examine the Postulate. Intervirology, 47, 2-13. https://doi.org/10.1159/000076636

62. Chu, P.G., Chang, K.L., Chen, Y.-Y., Chen, W.-G. and Weiss, L.M. (2001) No Significant Association of Epstein-Barr Virus Infection with Invasive Breast Carcinoma. The American Journal of Pathology, 159, 571-578. https://doi.org/10.1016/S0002-9440(10)61728-2

63. Al-Alwany, S. and Ali, S. (2013) Molecular Detection of Human Cytomegalovirus in Iraqi Patients with Breast Cancer. IJABR, 3, 454-459.

64. Utrera-Barillas, D., Valdez-Salazar, H.-A., Gómez-Rangel, D., Alvarado-Cabrero, I., Aguilera, P., Gómez-Delgado, A., et al. (2013) Is Human Cytomegalovirus Associated with Breast Cancer Progression? Infectious Agents and Cancer, 8, 12. https://doi.org/10.1186/1750-9378-8-12

65. Lee, S. and Schmitt, C.A. (2003) Chemotherapy Response and Resistance. Current Opinion in Genetics \& Development, 13, 90-96. https://doi.org/10.1016/S0959-437X(02)00014-X

66. Michaelis, M., Doerr, H.W. and Cinatl, J. (2009) Oncomodulation by Human Cytomegalovirus: Evidence Becomes Stronger. Medical Microbiology and Immunology, 198, 79-81. https://doi.org/10.1007/s00430-009-0107-8

67. Powers, C., DeFilippis, V., Malouli, D. and Frueh, K. (2008) Cytomegalovirus Immune Evasion. Human Cytomegalovirus: Springer, 333-359. https://doi.org/10.1007/978-3-540-77349-8_19

68. Hirano, T. (1998) Interleukin 6 and Its Receptor: Ten Years Later. International Reviews of Immunology, 16, 249-284. https://doi.org/10.3109/08830189809042997

69. Deroo, B.J. and Korach, K.S. (2006) Estrogen Receptors and Human Disease. The Journal of Clinical Investigation, 116, 561-570. https://doi.org/10.1172/JCI27987 